\title{
Unsuspected fractures of the femoral neck in patients with chronic hip pain due to rheumatoid arthritis
}

\author{
P L WILLIAMS, N K AMIN, A YOUNG
}

In patients with rheumatoid arthritis pain and loss of mobility due to diseased hip joints may disguise a superimposed fracture of the neck of the femur, particularly when there is no history of trauma.

\section{Case reports}

The table summarises five cases of rheumatoid arthritis in which a fracture of the neck of the femur was initially unsuspected. All five of the patients were postmenopausal women; three had received long term corticosteroids.

Department of Rheumatology, Middlesex Hospital, London W1

P L WILLIAMS, MRCP, senior registrar

N K AMIN, MB, BS, senior house officer

City Hospital, St Albans, Hertfordshire

A YOUNG, MRCP, consultant rheumatologist

Correspondence to: Dr P L Williams, Medway Hospital, Gillingham, Kent ME7 5NY.
Fractures of the femoral neck in chronic rheumatoid arthritis may be overlooked because of pre-existing hip pain due to rheumatoid disease

All had had chronic hip pain before their fractures. Three did not give a history of trauma (cases 2,4 , and 5), and the patient in case 3 , who had had a fall, did not describe any increase in hip pain; the presence of early callus on a pelvic radiograph suggested that the fracture may have preceded her fall.

\section{Discussion}

Despite the generalised osteoporosis often found in chronic rheumatoid arthritis ${ }^{1}$ the incidence of fractures of the neck of the femur in the disease has been reported as either the same as or only 1.5 times higher than that in the general population. ${ }^{23}$ There is, however, a risk of delay in diagnosing fractures in rheumatoid arthritis, particularly stress fractures; these may occur secondary to

Details of five women with chronic seropositive, erosive rheumatoid arthritis and fractured neck of femur

\begin{tabular}{|c|c|c|c|c|c|c|c|}
\hline Case No & $\begin{array}{c}\text { Age } \\
\text { (years) }\end{array}$ & $\begin{array}{l}\text { Duration of } \\
\text { disease } \\
\text { (years) }\end{array}$ & $\begin{array}{l}\text { Duration of } \\
\text { corticosteroid } \\
\text { treatment }\end{array}$ & $\begin{array}{l}\text { Mode of } \\
\text { presentation }\end{array}$ & $\begin{array}{l}\text { Time from } \\
\text { presentation } \\
\text { to radiograph } \\
\text { of pelvis }\end{array}$ & $\begin{array}{l}\text { Radiographic } \\
\text { findings }\end{array}$ & Management \\
\hline 1 & 57 & 28 & Past 24 years & $\begin{array}{l}\text { Exacerbation of } \\
\text { bilateral hip pain after } \\
\text { presumed grand mal fit } \\
\text { while awaiting surgical } \\
\text { cervical fusion as } \\
\text { inpatient }\end{array}$ & Three days & $\begin{array}{l}\text { Bilateral subcapital } \\
\text { fractures. Rheuma- } \\
\text { toid changes in both } \\
\text { hips }\end{array}$ & $\begin{array}{l}\text { Cervical fusion; } \\
\text { bilateral total hip } \\
\text { replacement six days } \\
\text { later }\end{array}$ \\
\hline 2 & 60 & 19 & $\begin{array}{l}\text { For eight years from } \\
\text { onset of disease }\end{array}$ & $\begin{array}{l}\text { Admitted for } \\
\text { treatment of leg ulcer; } \\
\text { exacerbation of pain in } \\
\text { right groin for three } \\
\text { weeks, treated with } \\
\text { analgesics by general } \\
\text { practitioner. No } \\
\text { trauma }\end{array}$ & $\begin{array}{l}\text { Two days after } \\
\text { admission; } 23 \text { days after } \\
\text { presentation to general } \\
\text { practitioner }\end{array}$ & $\begin{array}{l}\text { Right subcapital } \\
\text { fracture. Old fracture } \\
\text { of both pubic rami. } \\
\text { Rheumatoid changes } \\
\text { in both hips }\end{array}$ & $\begin{array}{l}\text { Right total hip } \\
\text { replacement; pinch } \\
\text { graft of leg ulcer }\end{array}$ \\
\hline 3 & 77 & 30 & Past 29 years & $\begin{array}{l}\text { Admitted because of } \\
\text { generalised } \\
\text { exacerbation of joint } \\
\text { pains. Had fallen at } \\
\text { home four days } \\
\text { previously. No } \\
\text { increase in hip pain }\end{array}$ & One day & $\begin{array}{l}\text { Right subcapital } \\
\text { fracture with early } \\
\text { callus formation. } \\
\text { Rheumatoid changes } \\
\text { in both hips }\end{array}$ & $\begin{array}{l}\text { Right total hip } \\
\text { replacement }\end{array}$ \\
\hline 4 & 84 & 11 & & $\begin{array}{c}\text { Routine outpatient } \\
\text { appointment: mild } \\
\text { generalised } \\
\text { exacerbation of joint } \\
\text { pains. No trauma }\end{array}$ & Same day & $\begin{array}{l}\text { Left subcapital } \\
\text { fracture. Rheumatoid } \\
\text { changes in both hips }\end{array}$ & $\begin{array}{l}\text { Left total hip } \\
\text { replacement }\end{array}$ \\
\hline 5 & 70 & 27 & & $\begin{array}{l}\text { Admitted with } \\
\text { increased pain in right } \\
\text { hip and difficulty } \\
\text { walking. No trauma }\end{array}$ & $\begin{array}{l}\text { 1st, same day; 2nd, five } \\
\text { days later }\end{array}$ & $\begin{array}{l}\text { Old fracture of left } \\
\text { pubic ramus. } \\
\text { Rheumatoid changes } \\
\text { in both hips. Right } \\
\text { subcapital fracture }\end{array}$ & $\begin{array}{l}\text { Right total hip } \\
\text { replacement }\end{array}$ \\
\hline
\end{tabular}




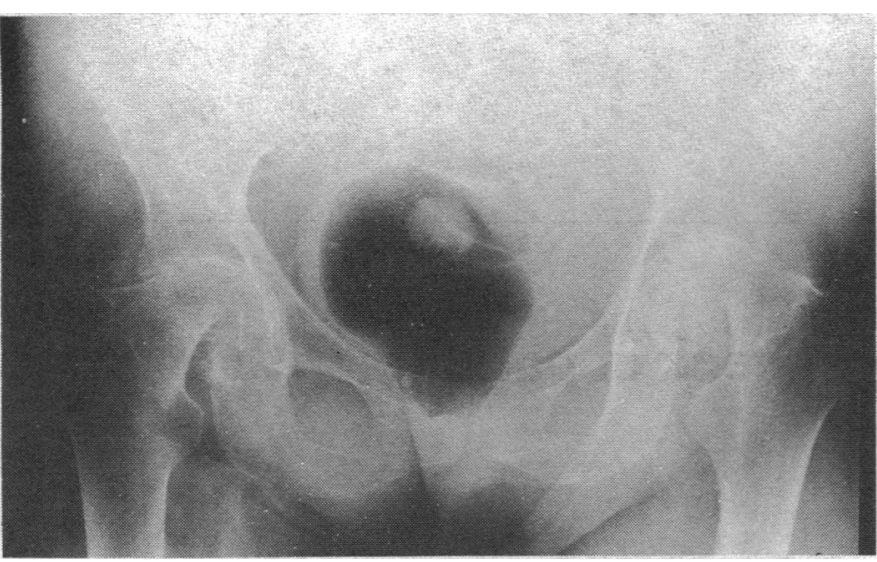

Radiograph of the pelvis showing bilateral displaced subcapital fractures and rheumatoid changes in both hips (case 1).

deformity at the knee or ankle and cause pain that is mistakenly thought to arise from the joint itself. ${ }^{+}$

In cases 1-4 diagnosis was delayed because fractures were not suspected clinically despite a recent increase in hip pain; in cases 3 and 4 the increase in pain was part of a generalised exacerbation of rheumatoid arthritis and the hip fractures were incidental findings on pelvic radiographs taken to assess progression of joint disease. In case 5 an undisplaced fracture was overlooked on an initial radiograph and detected only on a second radiograph five days later, during which time the patient had been mobilised. Thus any $c$ increase in hip pain in rheumatoid arthritis should raise the suspicion of fracture; other causes to consider are septic arthritis, $\overline{\bar{J}}$ ischaemic necrosis of the femoral head, osteomalacia, and exacerbation of synovitis of the hip.

Total replacement of the hip was performed in each of these five patients because of the risk of a femoral prosthesis alone protruding into the pelvis. All operations were successful, and the chronic hip pain was relieved.

Early recognition of these fractures is essential if unnecessary pain, immobilisation, and deformity are to be avoided.

\section{References}

1 Duncan H, Frost HM, Villanueva AR, Sigler JW. The osteoporosis of rheumatoid arthritis. Arthritis Rheum 1965;8:943-54.

2 Currie AL, Reid DM, Brown N, Nuki G. An epidemiological study of fracture of the neck of femur in the general population and in patients with rheumatoid arthritis. British foumal of

3 Hooyman JR, Melton LJ, Nelson AM, O'Fallon WM, Riggs BL. Fractures after rheumatoid arthritis: a population based study. Arthritis Rheum 1984;27:1353-61.

Young A Kinsella P, Boland P. Stress fractures of the lower limb in patients with rheumatod arthritis. $f$ Bone foint Surg $[B r] 1981 ; 63: 239-43$.

(Accepted 6 January 1986)

\section{Medicine and the Media}

T FOUND CLIVE Donner's documentary on motor neurone 1 disease, The Best Kept Secret (Channel 4, 16 April), to be compelling watching. It began with patients describing how the disease made simple activities of daily living impossible and handicapped them in other ways. All the patients had encountered difficulties in trying to find more information about the disease both from some of their medical advisers and from other sources. One was left with a strong feeling that doctors either don't know much about the disease or are not willing to talk to their patients about it.

Professor David Marsden gave a lucid and simple description of the areas of the nervous system affected by the disease and later discussed our lack of progress towards understanding its aetiology or developing treatment. Jan Way, the patient services officer of the Motor Neurone Disease Association, was very good. She described the best ways to maintain the patients' quality of life using aids.

Several messages came through strongly from the patients, who were slightly younger than an average group with motor neurone disease. Most had appreciable dysarthria, but even the most dysarthric and physically handicapped were intellectually preserved. The sense of helplessness, frustration, anger, and bitterness that many such patients and their relatives experience was clearly evident. One striking feature, however, was that the patients seemed generally to have come to terms with these emotions and to have harnessed them for their own benefit; but their close relatives were much more disturbed. The inexorably progressive nature of this disease was poignantly illustrated when it became clear that most of the sufferers who had talked in the early part of the programme had died within a year of their interviews and before this broadcast.

Some opportunities to communicate facts about the disease were not taken. It should have been emphasised more that, although we don't know what causes motor neurone disease, it is not contagious, or except in extremely rare cases inherited and that pain is not a primary symptom.

We doctors must talk more openly to our patients about motor neurone disease. We should also remember that in rapidly pro- gressive conditions like motor neurone disease it is no good taking eight months to provide aids or modify the patient's home to try to improve their quality of life-they may by then be too disabled to benefit.

This programme helped to make motor neurone disease a less $\stackrel{\mathbb{Q}}{\varrho}$ well kept secret to the lay public. Let us all hope that with time and $\overrightarrow{\overrightarrow{0}}$ increasing knowledge the "secret" of the aetiology of the disease will 3 also be discovered and that this will lead to an effective treatment.TIMOTHY WALLS, research associate in neurology, Newcastle upon Tyne.

WHEN SALVADOR DALI and Luis Bunuel made their experimental film Un Chien Andalou in 1931, the opening $\delta$ bizarre sequence showed a young woman apparently leaning back in $\frac{3}{3}$ a chair and having her left eyeball sliced open with a cut throat razor: 0 the effect, said the enfants terribles of surrealism, would "shock the onlooker into a state of free association" and would enable him the of better to appreciate the weird scenes that followed. I was reminded $D$ of this technique by the first few moments of the videotape Prescribing for the Elderly (Envision Productions, Kemicon Ltd, N Marsh Chambers, 27 Marsh Parade, Newcastle, Staffs, £46 స్ inclusive), which show elderly people being put through their paces 0 by energetic nurses and physiotherapists. Jolly music will enliven any viewer who might welcome the prospect of yet another therapeutic exhortation with less than a glad cry, and the hospital $\stackrel{\infty}{\rightarrow}$ scenes do indeed concentrate the attention. (I did not free associate $T$ once, as far as I could tell.)

The tape aims at teaching pharmacology and therapeutics and $\stackrel{\vec{D}}{\Omega}$ uses a script written and spoken by Dr John Mucklow, a consultant $\stackrel{\mathbb{Q}}{\mathbb{Q}}$ in geriatric medicine. It is hard to be certain what audience it is intended for, but most doctors dealing with elderly patients could probably get something out of it. The amount of information imparted is rightly not large and is competently presented.

I had trouble with some of the graphics, however, which $\frac{0}{7}$ consisted largely of moving diagrams showing drug molecules? 